\title{
Use of photodynamic therapy in the treatment of bovine subclinical mastitis
}

\author{
Lívia Helena Moreira $^{\mathrm{a}, \mathrm{b}}$, José Carlos Pereira de Souza ${ }^{\mathrm{c}}$, Carlos José de Lima ${ }^{\mathrm{a}, \mathrm{b}}$, \\ Miguel Angel Castillo Salgado , Adriana Barrinha Fernandes, ${ }^{\mathrm{a}, \mathrm{b}}$, Dora Inés Kozusny Andreani ${ }^{\mathrm{e}}$, \\ Antonio Balbin Villaverde ${ }^{\mathrm{a}, \mathrm{b}, *}$, Renato Amaro Zângaro ${ }^{\mathrm{a}, \mathrm{b}}$ \\ a Universidade Anhembi Morumbi (UAM), Rua Casa do Ator, 294, Campus Vila Olímpia, CEP 04546-001, São Paulo, SP, Brazil, \\ ${ }^{\mathrm{b}}$ Centro de Inovação, Tecnologia e Educação (CITÉ), Estrada Dr. Altino Bondesan, 500, Distrito de Eugênio de Melo, CEP 12247-016, São José dos Campos, SP, Brazil, \\ ${ }^{\mathrm{c}}$ Ministério da Agricultura, Pecuária e Abastecimento (MAPA), Av. Rodrigues Alves 129, $7^{\circ}$ andar, Praça. Mauá, Centro, CEP 20081-250, Rio de Janeiro, RJ, Brazil, \\ d Universidade do Estado de São Paulo (UNESP), Avenida José Longo, 777, Jardim São Dimas, CEP 12245-000, São José dos Campos, SP, Brazil \\ e Universidade Brasil (UNIBRASIL), Estrada Projetada F-1, s/n - Fazenda Santa Rita, CEP 15600-000, Fernandópolis, SP, Brazil
}

\section{A R T I C L E I N F O}

\section{Keywords:}

Disease of cows

Dairy cows

Phototherapy

Red LED

Photosensitizer

Veterinary medicine

\begin{abstract}
A B S T R A C T
Background: Bovine mastitis is a disease that causes a severe drawback in dairy production. Conventional treatments with antibiotic could leave antibiotic residues in the milk. The aim of this study was to evaluate the effect of photodynamic therapy in the treatment of bovine subclinical mastitis to develop an in vivo therapeutic protocol that could be used in routine farm practice, favoring the early return to production.

Methods: Forty cows with subclinical mastitis $(n=40)$ were divided into 4 groups (control, photodynamic therapy - PDT, light irradiation - LED, and photosensitizer - PS). Control group received no treatment, PDT group received application of $1.0 \mathrm{~mL}$ of $2.5 \%$ toluidine blue photosensitizer followed by LED irradiation at $\lambda=635 \mathrm{~nm}$, the LED group was treated with LED irradiation alone, and the PS group received only $2.5 \%$ toluidine blue dye. LED irradiation was applied to the mammary gland by means of an acrylic light guide coupled to the LED equipment. The PDT and LED groups were irradiated with $200 \mathrm{~J} / \mathrm{cm}^{2}$ at three different positions inside the mammary gland. Milk samples were collected at $0 \mathrm{~h}, 12 \mathrm{~h}, 24 \mathrm{~h}$ after treatment for microbial identification and total bacterial count.

Results: The treatment of the PDT group showed significant difference $\mathrm{p}<0.05$, characterizing the efficiency of this technique with the reduction of the microorganisms Streptococcus dysgalactiae and coagulase-negative Staphylococcus.

Conclusion: Photodynamic therapy was effective when applied in vivo for subclinical bovine mastitis. There was no need to separate the animal from production.
\end{abstract}

\section{Introduction}

Mastitis is a mammary gland inflammation that can be classified as clinical, subclinical and chronic mastitis. Although mastitis occurs sporadically in all mammalian species, its impact is of major economic importance in dairy cattle production, since milk production is of the most importance for humans [1].

In the form of clinical mastitis there is edema, warmth, pain and hardening of the mammary gland, in many cases with easy diagnosis. When mammary glands with mastitis are not easily diagnosed by palpation or visual examination of changes of the milk aspect the mastitis is classified as sub-clinical. The diagnosis of the subclinical mastitis depends largely on indirect tests such as the California Mastitis Test (CMT), which show the number of polymorphonuclear cells contained in the milk [1].

Although the treatment of subclinical mastitis have been studied for many years the disease still causes great losses in milk production [2]. Several studies report large economic losses related to the different types of mastitis found in cattle, from reduced milk production, drug costs and veterinary care [3-5].

High performance technologies in dairy production have increasingly depended on the use of veterinary drugs to treat cow diseases; among these drugs we can mention the antimicrobials used to treat mastitis. Microbial resistance to antimicrobials drugs is routinely

\footnotetext{
* Corresponding author at: Centro de Inovação, Tecnologia e Educação, CITE. Estrada Dr. Altino Bondensan, 500 Distrito de Eugênio de Melo, CEP: 12.247-016, São José dos Campos, SP, Brazil.

E-mail addresses: lh.medicinaveterinaria@gmail.com (L.H. Moreira), souzajcp@uol.com.br (J.C.P. de Souza), cdcflima@gmail.com (C.J. de Lima), miguel@fosjc.unesp.br (M.A.C. Salgado), dricabf@gmail.com (A.B. Fernandes), doraines@terra.com.br (D.I.K. Andreani), abvillaverde@gmail.com (A.B. Villaverde), razangaro@gmail.com (R.A. Zângaro).
} 
observed. Tests carried out in isolated Staphylococcus spp. and Gramnegative rods showed high levels of resistance to beta-lactam drugs, azithromycin, tetracycline, and doxycycline. [6-11]. Furthermore, milk could present residues of the drugs used for the treatment.

In the search for a new treatment alternative for microbial resistance, Photodynamic Therapy (PDT) is a promising strategy for the eradication of Gram-positive, Gram negative, yeast and fungal bacteria [12].

The mechanism of PDT is the activation of a non-toxic photosensitizer that through appropriate exposure to light at a convenient wavelength and energy density generates reactive oxygen species, including free radicals and singlet oxygen which, when in contact with the microorganisms, can modify bacterial DNA and cell membrane, leading to microbial death [13-15].

The effects of different photosensitizers (PS) on microorganisms are studied in vitro using a technique known as Photodynamic Inactivation (PDI). The PS when are activated by light radiation cause a deleterious microbial effect, which can be obtained by using light radiation with different wavelengths and energy densities [16]. Several studies about the deleterious action of PDI on microorganisms that cause mastitis have been reported, showing good results in in vitro experiments $[17,18]$.

Several published studies have discussed the use of the PDT technique in in vivo animal models mainly to treat the diseases that affect humans such as neoplasia [19-21] and periodontitis [22].

Therapeutic protocols using PDT in the veterinary clinical practice are still very scarce in literature, in wild animals there are reports of the application of the technique in pododermatitis in penguins [23], in farm animals was reported the use of the technique in sheep with abscesses of lymphadenitis [24], ocular carcinoma in cattle [25], and in pets in epidermoid carcinoma [26]. As far as the authors know there are not reports in the literature of in vivo studies on the use of PDT in treating dairy bovine mastitis

In this context, the present study aimed to evaluate the effect of photodynamic therapy in the treatment of subclinical mastitis in cattle in order to develop an in vivo therapeutic protocol that could be used in the routine of the dairy farm with the faster return of the animal to production.

\section{Materials and methods}

\subsection{Ethics statement}

The project was approved by the Animal Ethics Committee of Camilo Castelo Branco University under number 1-00034/2012.

\subsection{Animals}

The experiment was carried out in a rural property located in the city of Caçapava, São Paulo, Brazil.

All lactating cows $(n=164)$ at different stages of lactation were tested for subclinical mastitis using the California Mastitis Test (CMT) score, performed once a week before the first milking of the day. Cows $(\mathrm{n}=40)$ that showed positive CMT score for subclinical mastitis in four consecutive weeks were included in the experiment.

\subsection{Residual milk}

Six cows with a positive CMT score were randomly selected and after the automated milking process, the milk was manually depleted in the teat with mastitis, thus the quantity of residual milk after automated milking was determined, obtaining the value of $(145 \pm 23.3) \mathrm{mL}$ per teat/cow.

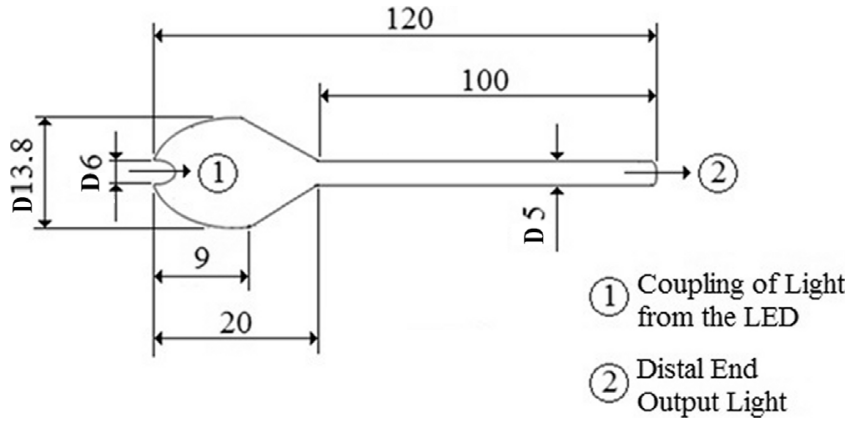

Fig. 1. Diagram of the acrylic light guide to be coupled to the LED equipment to allow irradiation to reach the infected mammary tissue. The measurements are expressed in $\mathrm{mm}$, and the letter $\mathrm{D}$ indicates that the dimension refers to the diameter.

\subsection{Photosensitizer (PS)}

The photosensitizing agent used trough the study was the toluidine blue at a concentration of $2.5 \%$ (Relva, Ribeirão Preto/SP, Brazil). Considering that $1 \mathrm{~mL}$ of $2.5 \%$ toluidine blue solution was injected in the mammary gland and the residual milk volume of $145 \mathrm{~mL}$, it was estimated a dye concentration inside the gland of $0.17 \mathrm{mg} / \mathrm{mL}$.

\subsection{LED equipment}

The Starlaser LED equipment (Microdont, Brazil), operating at wavelength $\lambda=635 \mathrm{~nm}$, with optical output power of $400 \mathrm{~mW}$ and power density of $2 \mathrm{~W} / \mathrm{cm}^{2}$ was used in the study. The output of the LED equipment was coupled to a cylindrical (acrylic) light guide measuring $100 \mathrm{~mm}$ in length by $5 \mathrm{~mm}$ in diameter (Fig. 1). The light guide was then introduced through the teat canal for the LED light to reach the mammary tissue affected by mastitis.

After coupling the acrylic optical guide to the LED equipment, the optical power was measured at the distal end of the guide, using the PM100D power meter (ThorLab, Newton, New Jersey, USA), obtaining the value of $150 \mathrm{~mW}$, corresponding to a power density of $0.76 \mathrm{~W} / \mathrm{cm}^{2}$. For this experiment an optical energy density of $200 \mathrm{~J} / \mathrm{cm}^{2}$ was established, which resulted in $260 \mathrm{~s}$ of LED light incidence on the mammary tissue during each irradiation.

\subsection{Treatment groups}

The treatments were always performed after milking, with all the animals $(n=40)$ confined in the place of milk collection. The cows were consecutively allocated into four equally divided experimental groups, and only one teat of each cow was selected for the study ( $\mathrm{n}=10$ teats per group): first group (Control) underwent no treatment, second group (PDT) was treated with LED radiation associated with $2.5 \%$ toluidine blue photosensitizer, third group (LED) was only irradiated with LED light, and fourth group (PS) was only treated with $2.5 \%$ toluidine blue photosensitizer.

In the PDT group, the treatment consisted of injecting $1.0 \mathrm{~mL}$ of $2.5 \%$ toluidine blue solution into the interior of the mammary gland by a catheter through the teat canal. The teat was then massaged for a better distribution of the photosensitizer inside the teat. Next, the light guide coupled to the LED equipment was introduced into the teat canal. A three-step procedure was used to irradiate the mammary tissue by changing the position of the distal end of the acrylic piece, as shown in Fig. 2. The first stage of light irradiation occurred after the distal end of the guide reached the glandular parenchyma (Fig. 3A). Afterwards, the acrylic piece was retracted until reaching the central region of the cistern gland, and thus, a second LED irradiation was carried out (Fig. 3B). For the last step, the guide was retracted until the distal end was positioned at the entrance of the cistern gland, where the third LED light irradiation was performed (Fig. 3C). Thus, the teat with mastitis 


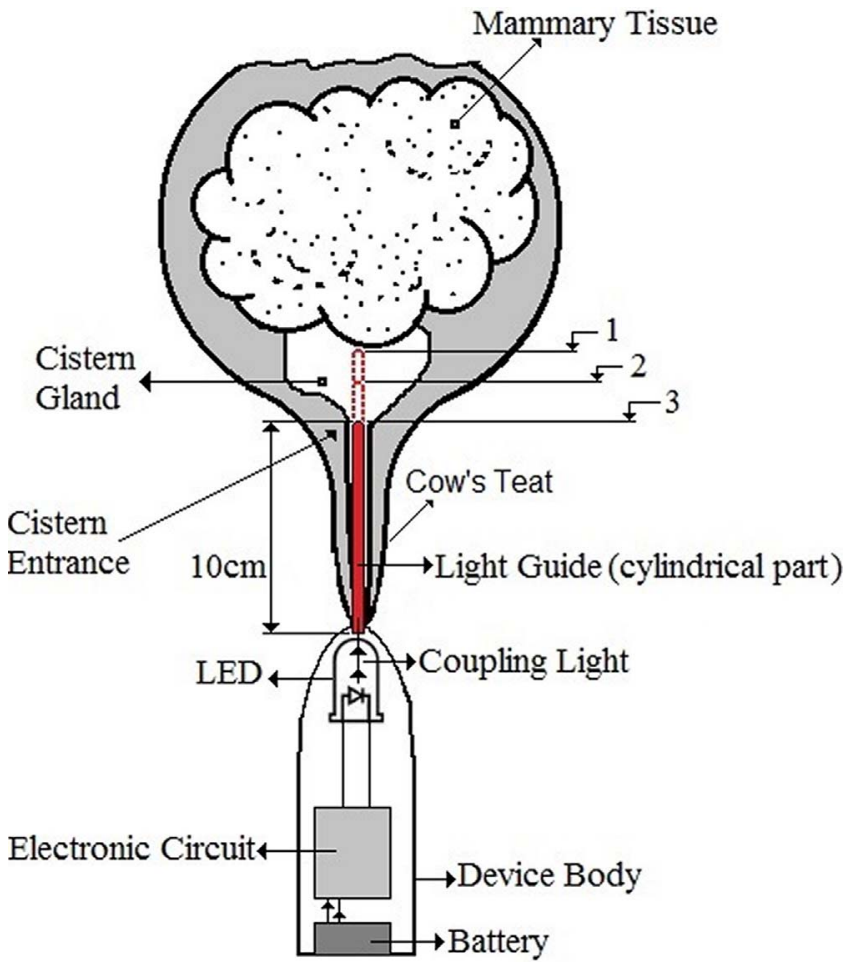

Fig. 2. Schematic view of the three-step LED irradiation of the teat with mastitis. Numbers 1, 2 and 3 indicated the positions of the distal end of the acrylic light guide in relation to the entrance of the cistern gland for each irradiation (dotted line).

treated with PDT received three applications of LED irradiation, each of $260 \mathrm{~s}$ and $200 \mathrm{~J} / \mathrm{cm}^{2}$ measured at the distal end of the light guide. After treatment, the animals remained in production and the milk was not discarded after milking. The teats of LED group were irradiated with LED light in $635 \mathrm{~nm}$ (red) using the same application protocol as the PDT group, without administration of the photosensitizer. Group PS: $1.0 \mathrm{~mL}$ of the $2.5 \%$ toluidine blue photosensitizer was applied inside the teat with mastitis; then, the teat was massaged for a better distribution of the photosensitizer inside the gland, no LED irradiation was applied. Control group: no treatment was applied to the teat with mastitis.
The acrylic optical guide was disinfected using 70\% ethanol before being introduced in the next cow for the irradiation session (Santa Cruz. Guarulhos, SP, Brazil).

\subsection{Milk sampling and bacteriological analysis}

Milk samples from all cows were harvested at $0 \mathrm{~h}, 12 \mathrm{~h}$ and $24 \mathrm{~h}$ after treatment, before milking and after sanitization of the teats. The samples were distributed in sterile bottles and transported to the microbiology laboratory in isothermal boxes containing ice. In the laboratory, the samples were processed in duplicate for microbial identification and total bacterial count. The total bacterial count was performed considering the initial dilution of 1:10, obtaining dilutions of $1: 100,1: 100,000$, and 1: 1000,000. Samples were seeded in blood agar base (Difco ${ }^{\circ}$ ) with $5 \%$ defibrinated sheep blood (Newproo ${ }^{\circ}$ ) and incubated in a bacteriological oven at $37^{\circ} \mathrm{C}$. Isolation and total bacterial counts were performed at $24 \mathrm{~h}$ and $48 \mathrm{~h}$ after incubation.

The morphological characteristics of the colonies such as size, type, staining, and presence of hemolysis were observed; then, were analyzed under microscope observation: morphology, arrangement of cells, Gram staining characteristics, and catalase test [27].

\subsection{Statistical analysis}

Data were analyzed using statistical analysis of variance (ANOVA) followed by the Tukey-Kramer multiple comparison test with significance level of $5 \%(p<0.05)$. The program used for statistical analysis was GraphPad Instat $3.0^{\circ}$ (GraphPad Software Inc, CA, USA)

\section{Results}

Analysis of the 164 cows tested showed a prevalence of $66.5 \%$ with mastitis, corresponding to $71.6 \%$ of subclinical mastitis and $28.4 \%$ of clinical mastitis. All 40 cows selected for the present study presented subclinical mastitis. Following the division of the groups, milk samples were collected from the cows of the study and six different microorganisms that cause the disease were isolated, as shown in Table 1. In some samples of milk with subclinical mastitis were isolated the three combined microorganisms coagulase negative Staphylococcus, Bacillus $s p$ and Corynebacterium $s p$

The logarithm of the total bacterial count $(\mathrm{CFU} / \mathrm{mL})$ of the PDT,
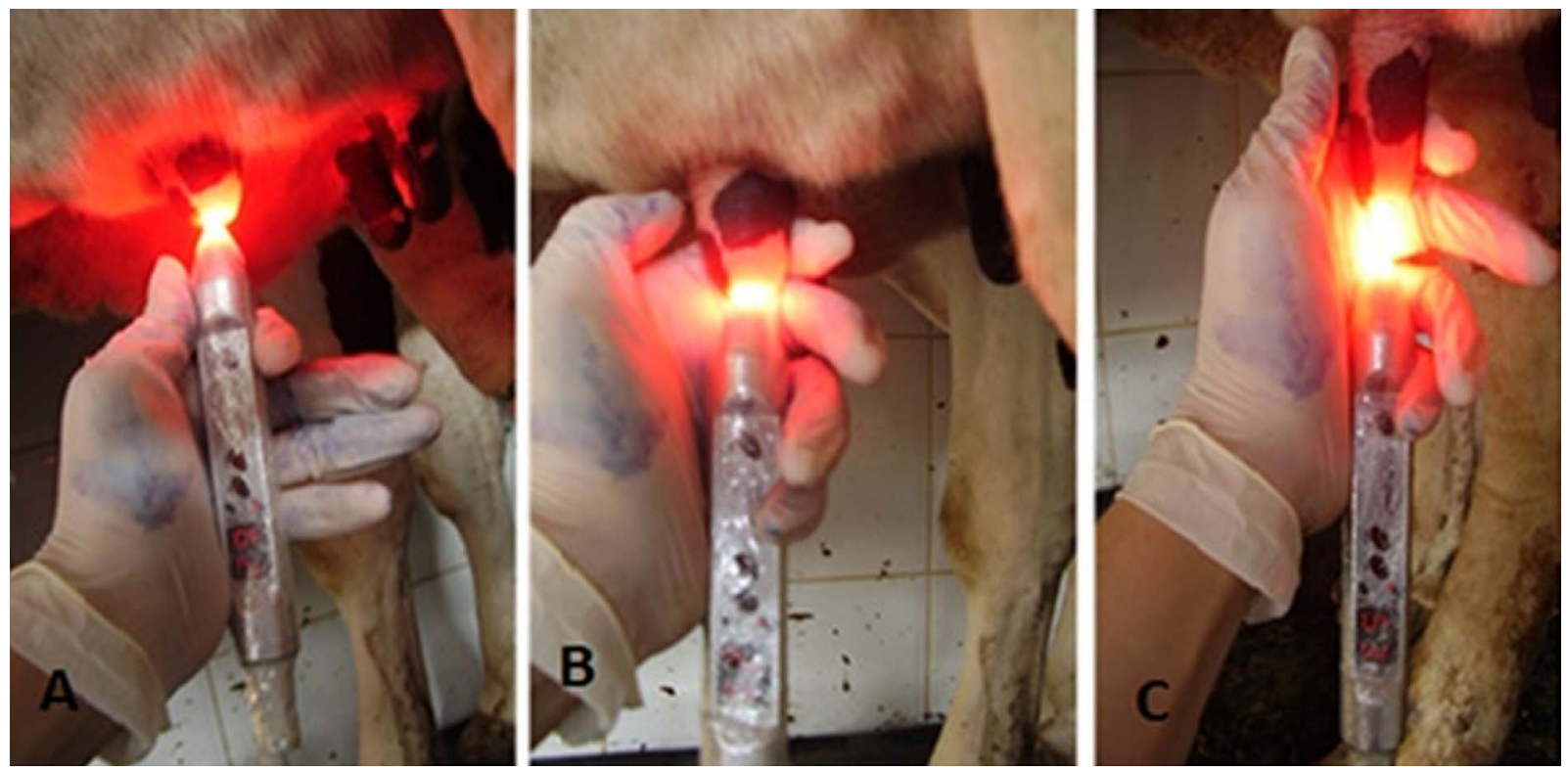

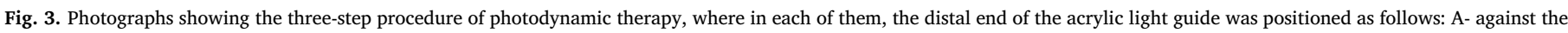
glandular parenchyma, B- the central region of the cistern gland, and C- entrance of the gland. 
Table 1

Number of milk samples per group in which microorganisms causing subclinical mastitis in dairy cattle were found and isolated.

\begin{tabular}{lllll}
\hline \multirow{2}{*}{ Microorganisms } & \multicolumn{2}{l}{ Groups } & & \\
\cline { 2 - 5 } & PDT & LED & PS & CONTROL \\
\hline Coagulase-negative Staphylococcus & 3 & 6 & 10 & 3 \\
Streptococcus dysgalactiae & 6 & 1 & 1 & 3 \\
Streptococcus bovis & 0 & 0 & 0 & 2 \\
Escherichia coli & 1 & 1 & 0 & 0 \\
Bacillus sp & 0 & 5 & 1 & 1 \\
Corynebacterium sp & 0 & 1 & 2 & 3 \\
\hline
\end{tabular}

LED, PS, and Control groups of subclinical mastitis at $0 \mathrm{~h}, 12 \mathrm{~h}$ and $24 \mathrm{~h}$ after treatment are shown in Fig. 4. After the microbiological survey, the results obtained in all treatment groups were statistically analyzed using the analysis of variance ANOVA, followed by the Tukey-Kramer multiple comparison test, at a 5\% significant level. The treatment of the PDT group was the only that presented a statistically significant difference $(\mathrm{p}<0.0001)$, indicating that the treatment was efficient in the reduction of the microorganisms involved in the bovine disease. The ANOVA test, followed by the Tukey-Kramer for the other three groups gave the following results: LED $-\mathrm{p}=0.19$, PS $-\mathrm{p}=0.48$ and Control $-\mathrm{p}=0.24$, showing that the treatments were not efficient in these groups.

To study the temporal evolution of the bacterial inactivation process in the PDT group, the ANOVA followed by the Tukey-Kramer multiple comparison test was applied, observing the following results: $0 \mathrm{~h}$ vs $12 \mathrm{~h}$ $-\mathrm{p}<0.001 ; 0 \mathrm{~h}$ vs $24 \mathrm{~h}-\mathrm{p}<0.001 ; 12 \mathrm{~h}$ vs $24 \mathrm{~h}-\mathrm{p}>0.05$, indicating that the inactivation was more significant in the first $12 \mathrm{~h}$ after irradiation. A 2-log bacterial reduction was found in the first $12 \mathrm{~h}$ followed by $1 \log$ between $12 \mathrm{~h}$ and $24 \mathrm{~h}$, totaling a 3-log bacterial reduction in the first $24 \mathrm{~h}$.

Bacteriological analysis of the PDT group showed the presence of Streptococcus dysgalactiae (5 animals), Escherichia coli (1 animal) and coagulase-negative Staphylococcus ( 3 animals). Fig. 5 presents the log of bacteria counts isolated from the PDT group at time intervals $0 \mathrm{~h}$, $12 \mathrm{~h}$, and $24 \mathrm{~h}$. A 2-log reduction for Streptococcus dysgalactiae and 5-log reduction for coagulase-negative Staphylococcus were found in the first $24 \mathrm{~h}$ after irradiation in the PDT group. However, treatment with PDT was not effective against Escherichia coli.

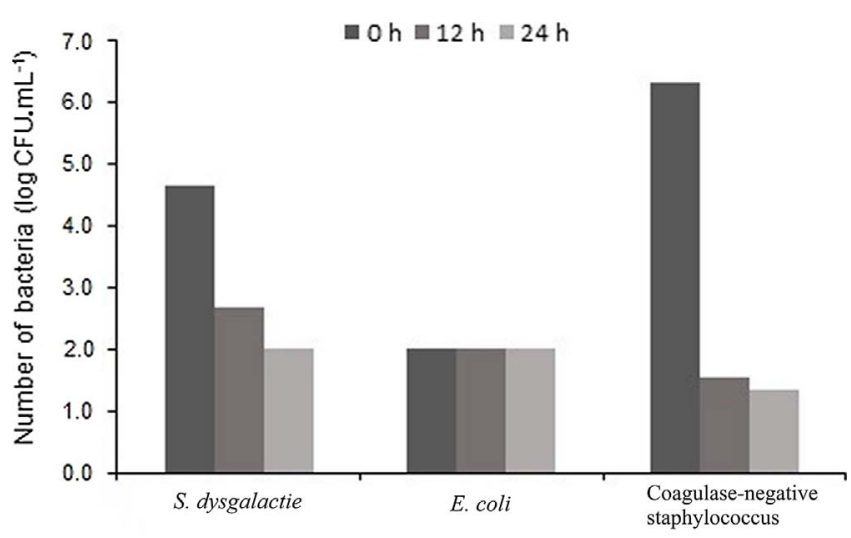

Microorganisms

Fig. 5. Mean value of the log of bacteria counts isolated from the PDT group at time intervals $0 \mathrm{~h}, 12 \mathrm{~h}$, and $24 \mathrm{~h}$.

\section{Discussion}

Mastitis has a high prevalence in dairy herd worldwide; for instance: Léon-Galván et al. [5] in their studies in Mexico found 39.1\% of subclinical mastitis and 9.3\% for clinical mastitis; Sinhá et al. [4] obtained in India $46 \%$ prevalence of infected animals by subclinical mastitis, while that Malik et al. [28] studying the micro-region of Cuiabá/MG in Brazil, found that $85.2 \%$ of the animals presented the mastitis in at least one teat, with clinical and subclinical mastitis being 5.8 and $65 \%$, respectively. In our study was obtained a total prevalence for mastitis of $66.5 \%$, of these $71.2 \%$ were subclinical mastitis and $28.4 \%$ clinical mastitis, demonstrating the importance of the study of new non-conventional treatments for this disease. Alencar et al. [9] while studying the microorganisms involved in mastitis in the State of Rio de Janeiro/ Brazil found $85.07 \%$ of Staphylococcus spp. and 14.93\% of Gram-negative rods. The same authors observed in their antimicrobial resistance tests high levels of resistance to beta-lactam antibiotics for Staphylococcus spp. and azithromycin, tetracycline and doxycycline in Gramnegative rods; therefore, making difficult to cure the disease using conventional methods with antibiotics.

Photodynamic therapy was initially applied in neoplasia and skin infections [29] and later in microorganisms [16-18,30]. It has become

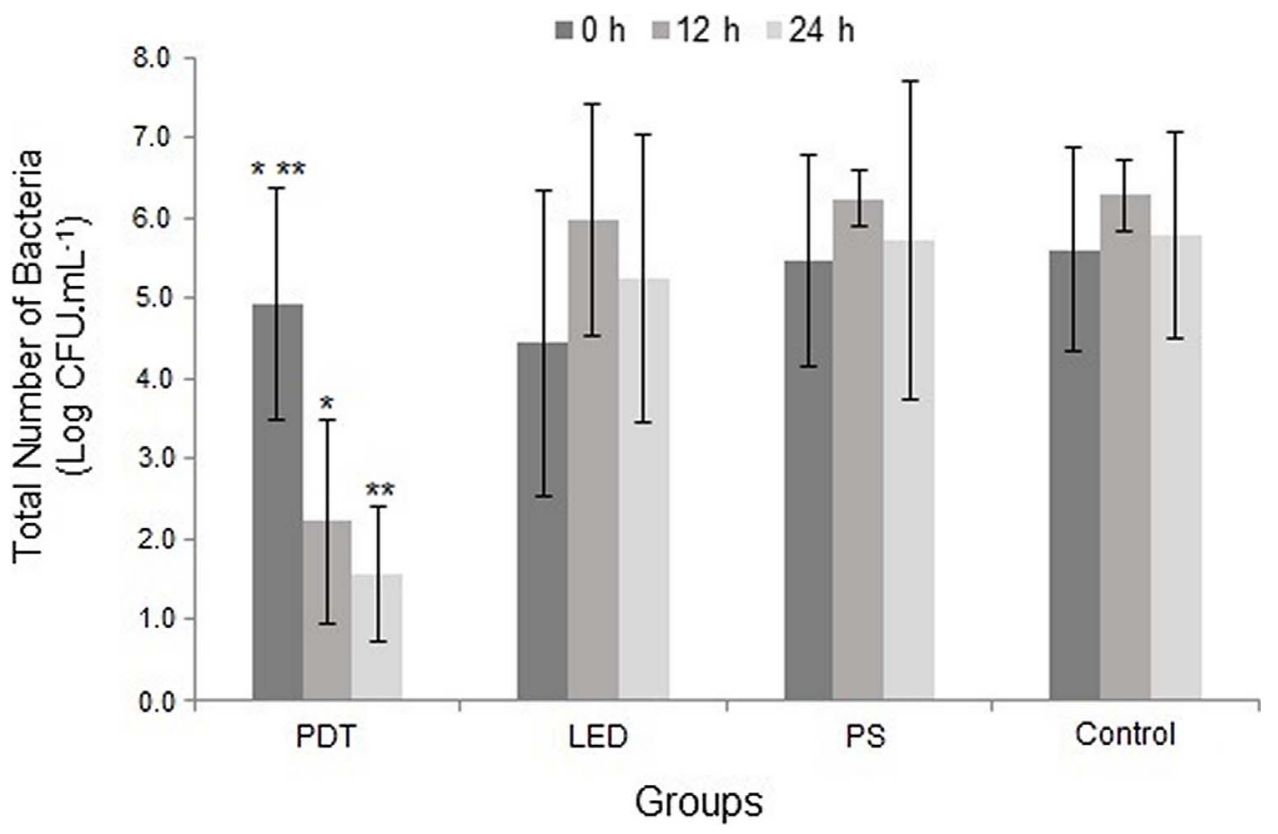

Fig. 4. Mean value and standard deviation of the logarithm of total bacterial count of the four experimental groups treated for subclinical mastitis at time intervals $0 \mathrm{~h}, 12 \mathrm{~h}$, and $24 \mathrm{~h}$ after irradiation. * $\mathrm{p}<0.001$ between $0 \mathrm{~h}$ and $12 \mathrm{~h}$ and $* * \mathrm{p}<0.001$ between $0 \mathrm{~h}$ and $24 \mathrm{~h}$, both in the PDT group. 
an increasingly promising antimicrobial therapy option, as there are no reports of microbial resistance to this therapy.

The bacteria Staphylococcus aureus, Streptococcus dysgalactiae, Streptococcus agalactiae, Corynobacterium bovis and Prototheca zopfii isolated from bovine mastitis have already been tested with photodynamic inactivation therapy (PDI) by applying $50 \mu \mathrm{M}$ of methylene blue as a photosensitizer and LED irradiation at a wavelength $\lambda=662 \mathrm{~nm}$, and optical power of $320 \mathrm{~mW}$ [18]. The authors submitted the microbiological samples to different energy densities in in vitro assays and they found at $3 \mathrm{~J} / \mathrm{cm}^{2}$ irradiation a bacterial reduction of Staphylococcus aureus, Streptococcus dysgalactiae and Corynobacterium bovis, being $C$. bovis samples more susceptible to PDI with 1-3.5-log reduction in comparison with the other species. They also observed that Streptococcus agalactiae and Prototheca zopfii underwent complete inactivation when irradiated with the higher energy densities of $12 \mathrm{~J} / \mathrm{cm}^{2}$ and $18 \mathrm{~J} / \mathrm{cm}^{2}$, respectively.

In other in vitro assay using $E$. coli was reported a partial reduction of this agent when compared to $S$. aureus, when both were inactivated with the use of photosensitizer toluidine blue and radaclorin [16]. The low rate of inactivation of $E$. coli was also reported when the milk infected with this bacterium was treated with pulsed light. The authors concluded that this low inactivation could have occurred due to the concentration of the bacterium in the milk, and light absorption by the solid materials and fat in the milk, making difficult the bacterium inactivation [31].

These in vitro assays corroborate our results in vivo as we observed 2$\log$ reductions of Streptococcus dysgalactiae, 5-log reduction of coagulase negative Staphylococcus, but did not observe change in the total bacterial count of Escherichia coli, even after three applications of LED irradiation at $200 \mathrm{~J} / \mathrm{cm}^{2}$

Hamblin et al. [32] stated that photosensitizers penetrating inside the bacteria can be more effective than those acting only on the bacterial surface. This fact is relevant to explain why the diversity of bacteria found in cows with subclinical mastitis present different responses to therapeutic treatment proposed.

It can be observed for the groups that receive only photosensitizer or LED irradiation alone a partial reduction of the microorganisms that cause mastitis disease. Our data corroborate the in vitro essays reported in the literature [16-18],

When evaluating in vivo animal assays using photodynamic therapy, most studies report the use of the technique in fully controlled experimental models, such as in mice with cutaneous and oral infections by fungi, and in neoplasms $[33,34]$. Those experiments differ from the present study since our main objective was to apply the photodynamic therapy technique in the routine of a dairy farm, despite all the variables that can be found in a farm, and making the therapeutic practice promising for the dairy sector as there is no need to discard the milk from the treated teat and the technique does not induce the phenomenon of microbial resistance, as antibiotic therapy promotes.

Studies reporting clinical veterinary treatment using photodynamic therapy are still scarce in the literature, the most common are case report studies, such as an equine that received PDT for the surgical removal of giant cell carcinoma of the epidermis [35], application of PDT in abscesses of caseous lymphadenitis in sheep using methylene blue as a photosensitizer with fluence of $133.3 \mathrm{~J} / \mathrm{cm}^{2}$ [24], and in the treatment of footpad dermatitis (bumblefoot) in penguins comparing conventional treatment with the PDT technique [23].

Nascimento et al. [23] carried out in vitro and in vivo studies with Magellanic penguins using photodynamic therapy. In their in vitro assay to test the microbial inactivation of the lesions, PDI was applied with $300 \mu \mathrm{M}$ methylene blue photoactivated with laser irradiation of $133.3 \mathrm{~J} / \mathrm{cm}^{2}$. In that study, they found bacterial death according to the time of exposure to irradiation. Bacteria S. aureus and Pseudomonas aeruginosa were efficiently inactivated, but this did not occur in the samples where $E$. coli was isolated, reporting the difficulty of inactivation of this bacterium, which corroborates data found in the present study of subclinical mastitis in cows. In relation to the in vivo assay, those authors observed that the group of penguins that was treated with PDT presented a better performance than the group treated with antibiotics in the first month of the treatment, because PDT was directly applied on the lesion, eliminating a great number of microorganisms without injured more the infected tissue [24].

It was not found in the literature reports of using PDT for the treatment of dairy cows mastitis.

Although there are few published studies investigating specific therapeutic protocols for animal diseases, the PDT technique is extremely promising in veterinary clinical practice and it can be used routinely.

\section{Conclusion}

The results obtained in the present study allow us to conclude that photodynamic therapy was efficient when applied in vivo to treat subclinical mastitis in cows, without the need to remove the animal from production. Further studies should be carried out to develop other therapeutic protocols because of the diversity of microorganisms involved in the mastitis.

\section{Conflicts of interest}

The authors declare there is no potential conflict of interest regarding this work.

\section{Funding}

The present project was granted financial support from Conselho Nacional de Desenvolvimento Científico e Tecnológico do Brasil (CNPq) for the present study (Process 140656/2005-7).

\section{Acknowledgments}

We thank Anhembi Morumbi University for their support and encouragement; Microdont for loaning the equipment used to conduct the research; Mr. Alemar, the veterinarian from the Frigorífico Mantiqueira of São José dos Campos; Dr. Carmen Quaglia, responsible for the Laboratory Quaglia, for the microbiological analyses, and especially Professor Dr. Nicolau Maués da Serra-Freire for the scientific support.

\section{References}

[1] D.C. Blood, O.M. Radostitis, Veterinary Medicine A Textbook of the Diseases of Cattle, Sheep, Pigs, Goats and Horses, seventh ed., Baillière Tindal, 1990, 2017 1502 p.

[2] G.J. Wellenberg, W.H.M. Poel, J.T. Oirschot, Viral infections and bovine mastitis: a review, Vet. Microbiol. 88 (2002) 27-45.

[3] T. Halasal, K. Huijps, O. Osterds, H. Hogeveen, Economic effects of bovine mastitis and mastitis management: a review, Vet. Q. 29 (2007) 18-31, http://dx.doi.org/10. 1080/01652176.2007.9695224.

[4] M. Kr. Sinhá, N.N. Thombare, B. Mondal, Subclinical mastitis in dairy animals: incidence, economics, and predisposing factors, Sci. World J. (2014) 523984, http://dx.doi.org/10.1155/2014/523984.

[5] M.F. León-Galván, J.E. Barboza-Corona, A.A. Lechuga-Arana, M. Valencia-Posadas, D.D. Aguayo, C. Cedillo-Pelaez, A.J. Gutierrez-Chavez, Molecular detection and sensitivity to antibiotics and bacteriocins of pathogens isolated from bovine mastitis in family dairy herds of Central Mexico, Biomed. Res. Int. (2015) 615153, http:// dx.doi.org/10.1155/2015/615153.

[6] L.H.M. Silva, Tratamento De Mastite Subclínica Utilizando Terapia Fotodinâmica (PDT). Tese (Doutorado), Universidade Federal Rural do Rio de Janeiro, Programa de Pós-Graduaç̃o em Ciências Veterinárias, 200983 p.

[7] M.H. Fabres-Klein, M.J.C. Santos, R.C. Klein, G.N. Souza, A.O.B. Ribon, An association between milk and slime increases biofilm production by bovine Staphylococcus aureus, BMC Vet. Res. 11 (2015) 3, http://dx.doi.org/10.1186/ s12917-015-0319-7.

[8] W. Wang, Y. Song, K. Petrovski, P. Eats, D.J. Trott, H.S. Wong, S.W. Page, J. Perry, S. Garg, Development of intramammary delivery systems containing lasalocid for the treatment of bovine mastitis: impact of solubility improvement on safety, efficacy, and milk distribution in dairy cattle, Drug Des. Dev. Ther. 9 (2015) 631-642, http://dx.doi.org/10.2147/DDDT.S74731. 
[9] T.A. Alencar, E.C.L. Mendonça, V.F. Marques, D.A. Melo, A.C.M. Rojas, C.C. Motta, G.S. Santiago, F.C. Dubenczuk, P.T.C. Medeiros, S.M.O. Coelho, M.M.S. Souza, Aspectos das condições higiênico-sanitárias em unidades leiteiras em municípios do estado do Rio de Janeiro, Brasil e análise dos agentes bacterianos envolvidos na etiologia das mastites, Rev. Bras. Med. Vet. 36 (2014) 199-208.

[10] B.R. Pribul, I.A. Pereira, L.C. Soares, S.M.O. Coelho, I.L. Barberis, L. Pascual, M.M.S. Souza, Bacterial resistance and bacteriocins action in Staphylococcus aureus isolated from bovine mastitis, Arq. Bras. Med. Vet. Zootec. 63 (3) (2011) 744-748, http://dx.doi.org/10.1590/S0102-09352011000300029.

[11] I.A. Pereira, L.C. Soares, S.M.O. Coelho, F.A. Balbino, B.R. Pribul, M.M.S. Souza, Azithromycin susceptibility pattern of bacterial isolated from different sites of infections in pet animals, Arq. Bras. Med. Vet. Zootec. 61 (2009) 577-584, http://dx. doi.org/10.1590/S0102-09352009000300009.

[12] F.F. Sperandio, H. Ying-Ying, M.R. Hamblin, Antimicrobial Photodynamic Therapy to kill gram-negative bacteria, Recent Pat Antiinfect. Drug Discov. 8 (2013) 108-120.

[13] A.P. Castano, T.N. Demidova, M.R. Hamblin, Mechanisms in photodynamic therapy: part one-photosensitizers, photochemistry and cellular localization, Photodiagnosis Photodyn. Ther. 1 (2004) 279-293, http://dx.doi.org/10.1016/ S1572-1000(05)00007-4.

[14] M.R. Hamblin, T. Hasan, Photodynamic therapy: a new antimicrobial approach to infectious disease? Photochem. Photobiol. Sci. 3 (2004) 436-450, http://dx.doi. org/10.1039/b311900a.

[15] S.P. Tseng, W.C. Hung, H.J. Chen, Y.T. Lin, H.S. Jiang, H.C. Chiu, P.R. Hsueh, L.J. Teng, J.C. Tsai, Effects of toluidine blue O (TBO) - photodynamic inactivation on community associated methicillin-resistant Staphylococcus aureus isolates, J. Microbiol. Immunol. Infect. 50 (2015) 46-54, http://dx.doi.org/10.1016/j.jmii. 2014.12.007.

[16] R. Fekrazada, H. Zarec, S. Mohammadi, S. Vandd, Photodynamic therapy effect on cell growth inhibition induced by radachlorin and toluidine blue $\mathrm{O}$ on Staphylococcus aureus and Escherichia coli: An in vitro study, Photodiagnosis Photodyn. Ther. 15 (2016) 213-217, http://dx.doi.org/10.1016/j.pdpdt.2016.07. 001.

[17] L. Gandara, L. Mamone, C. Dotto, F. Buzzola, A. Casas, Sae regulator factor impairs the response to photodynamic inactivation mediated by Toluidine blue in Staphylococcus aureus, Photodiagnosis Photodyn. Ther. 16 (2016) 136-141, http:// dx.doi.org/10.1016/j.pdpdt.2016.09.005.

[18] F.P. Sellera, P.C. Sabino, M.S. Ribeiro, R.G. Gargano, N.R. Benites, P.A. Melville, F.C. Pogliani, In vitro photoinactivation of bovine mastitis related pathogens, Photodiagnosis Photodyn. Ther. 13 (2016) 276-281, http://dx.doi.org/10.1016/j. pdpdt.2015.08.007.

[19] J. Lee, H.Y. Park, W.W. Kim, J.Y. Jeong, Y.D. Lee, M.H. Choi, S. Kim, J.Y. Park, J.H. Jung, Combination treatment with Photodynamic Therapy and Laser Ablation in breast cancer: an animal model study, Photomed. Laser Surg. 35 (2017) 505-512, http://dx.doi.org/10.1089/pho.2017.4291.

[20] L.C. Silva, J. Ferreira-Strixino, L.C. Fontana, G.A.M. Rocha, A.C. Serra, M. Pineiro, R. Canevari, A molecular analysis of apoptosis pathway after Photodynamic Therapy in breast cancer: animal model study, Photodiagnosis Photodyn. Ther. 14 (2016) 152-158, http://dx.doi.org/10.1016/j.pdpdt.2016.03.006.

[21] M.A. D'Hallewin, S. Berrahmoune, L. Bezdetnaya, L. Henri-Pierre, F. Guillemin, Orthotopic animal models for oncologic photodynamic therapy and photodiagnosis, Photodiagnosis Photodyn. Ther. 4 (2007) 230-236, http://dx.doi.org/10.1016/j. pdpdt.2007.09.001.
[22] E.L. Belinello-Souza, L.H. Alvarenga, C. Lima-Leal, P. Almeida, C.G. Leite, T.R. Lima, B. Godoy-Miranda, J. Previati-Oliveira, L. Pretto, A.Z. Freitas, A.U. Fernandes, R.L. Marcos, R.A. Prates, Antimicrobial photodynamic therapy combined to periodontal treatment: experimental model, Photodiagnosis Photodyn. Ther. 18 (2017) 275-278, http://dx.doi.org/10.1016/j.pdpdt.2017.03.008.

[23] C.L. Nascimento, M.S. Ribeiro, F.P. Sellera, G.H.P. Dutra, A. Simões, C.R. Teixeira, Comparative study between photodynamic and antibiotic therapies for treatment of footpad dermatitis (bumblefoot) in Magellanic penguins (Spheniscus magellanicus), Photodiagnosis Photodyn. Ther. 12 (2015) 36-44, http://dx.doi.org/10.1016/j. pdpdt.2014.12.012.

[24] F.P. Sellera, R.G. Gargano, Libera A.M.M.P.D, F.J. Benesi, M.R. Azedo, L.R.M. de Sá, M.S. Ribeiro, M.B. da Silva, F.C. Pogliani, Antimicrobial photodynamic therapy for caseous lymphadenitis abscesses in sheep: report of ten cases, Photodiagnosis Photodyn. Ther. 13 (2016) 120-122, http://dx.doi.org/10.1016/j.pdpdt.2015.12. 006.

[25] R. Hage, G. Mancilha, R.A. Zângaro, E. Munin, H. Plapler, Photodynamic Therapy (PDT) using intratumoral injection of the 5- aminolevulinic acid (5-ALA) for the treatment of eye cancer in cattle. Optical Methods for Tumor Treatment and Detection: Mechanisms and Techniques in Photodynamic Therapy XVI, SPIE 6427 (2007), 64271C. https://doi.org/10.1117/12.701316.

[26] R. Hage, J. Duarte, R.A. Zângaro, C.B. Lopes, M.T.T. Pacheco, Photodynamic therapy applied in the epidermoid carcinoma treatment: two experimental cases. Abstracts from the 5th Congress of the World Association for Laser Therapy, November 25-27, 2004, Sâo Paulo, Brazil, Photomed. Laser Surg. 23 (2005) 89-151, http://dx.doi.org/10.1089/pho.2005.23.89.

[27] O.W. Schalm, E.J. Jain, N.C. Jain, Bovine Mastitis, first ed., Lea \& Febiger, Philadelphia, 1971, pp. 249-282.

[28] R.P. Martins, J.A.G. Silva, L. Nakazato, V. Dutra, E.S.A. Filho, Prevalência e etiologia infecciosa da mastite bovina na microrregião de Cuiabá, MT. Ci, Anim. Bras. 11 (2010) 181-187, http://dx.doi.org/10.5216/cab.v11i1.5085.

[29] R.L. Lipson, E.J. Baldes, The photodynamic properties of a particular hematoporphyrin derivative, Arch. Dermatol. 82 (1960) 508-516.

[30] M. Miyabe, J.C. Junqueira, A.C.B.P. Costa, A.O.C. Jorge, M.S. Ribeiro, I.S. Feist, Effect of photodynamic therapy on clinical isolates of Staphylococcus spp, Braz. Ora Res. 25 (2011) 230-234.

[31] B.M. Miller, A. Sauer, C.I. Moraru, Inactivation of Escherichia coli in milk and concentrated milk using pulsed-light treatment, J. Dairy Sci. 95 (2012) 5597-5603, http://dx.doi.org/10.3168/jds.2012-5714.

[32] M.R. Hamblin, D.A. O‘Donnell, N. Murthy, K. Rajagopalan, N. Michaud, M.E. Sherwood, T. Hasan, Polycationic photosensitizer conjugates: effects of chain length and Gram classification on the photodynamic inactivation of bacteria, $\mathrm{J}$. Antimicrob Chemother. 49 (2002) 941-951.

[33] L.M. Baltazar, A. Ray, D.A. Santos, P.S. Cisalpino, A.J. Friedman, J.D. Nosanchuk, Antimicrobial photodynamic therapy: an effective alternative approach to control fungal infections, Front. Microbiol. 6 (2015) 202, http://dx.doi.org/10.3389/fmicb. 2015.00202.

[34] M. Hammad, M. Fakhar-e-Alam, M. Fatima, F. Shaheen, S. Iqbal, M. Atif, M. Talha, A.S. Mansoor, M. Afzal, A. Majid, T. Shelih Al Harbi, M. Ismail, Z.M. Wang, M.S. AlSalhi, Z.A. Alahmed, Photodynamic effect of Ni nanotubes on an HeLa cell line, PLoS One 11 (2016) e0150295, http://dx.doi.org/10.1371/journal.pone. 0150295.

[35] F. Cian, S. Whiteoak, J. Stewart, A case of giant cell tumor of soft parts in a horse, Vet. Clin. Pathol. 45 (2016) 501-504, http://dx.doi.org/10.1111/vcp.12377. 